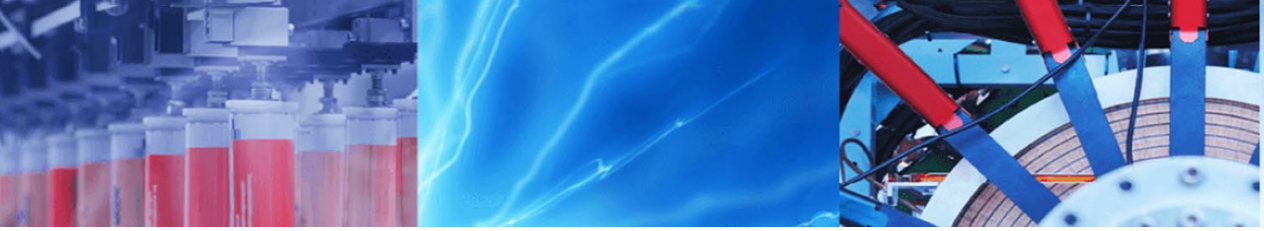

Research Article

\title{
Enhanced heavy metals biosorption using chemically modified chitosan coated microwave activated sugarcane baggage ash composite biosorbents
}

\author{
Linh My Nguyen ${ }^{1}$ (D) Tien Thuy Hoang Nguyen ${ }^{1}$ (D)
}

Received: 6 August 2019 / Accepted: 31 October 2019 / Published online: 6 November 2019

(c) Springer Nature Switzerland AG 2019

\begin{abstract}
In recent years, toxic pollutants in industrial wastewater are seriously considered as one of the environmental problems due to the heavy metals present in it. Currently, biosorption has been strongly recommended by researchers as an efficient and economical technique to reduce the amount of heavy metals in the different industrial wastewater sources. Chitosan and sugar bagasse ash are the well-known biosorbents due to their low cost, available and effective in adsorption process. In this study, the composite biosorbent was prepared by mixing chitosan and sugar bagasse ash prepared by microwaving at a ratio of 1:5 (ASB-CBs) in acid condition. Adsorbents were characterized by SEM analysis method and FTIR infrared spectra. The parameters affecting the $\mathrm{Pb}(\mathrm{II})$ and $\mathrm{Cd}$ (II) adsorption such as $\mathrm{pH}$, adsorption time, dose of adsorbent was studied by running the batch experiments. Research data show that the optimal $\mathrm{pH}$ for the biosorption process is 5.0. Experimental data is described by the Freundlich equation. Thermodynamic process is also studied in which the negative free Gibbs energy indicated the metal ions adsorption on the ASB-CBs was spontaneous and endothermic nature.
\end{abstract}

Keywords Chitosan · Microwave charcoal · Sugarcane baggage ash · Composite biosorbents · Heavy metal removal

\section{Introduction}

In recent years, toxic pollutants in industrial wastewater is seriously considered as one of the environmental problems due to the heavy metals present in it. These contaminants are not decomposable easily and seriously to affect human health through the food chain causing various diseases and disorders. Among these contaminants, lead and cadmium are recurrently found together, for example, in the wastewater of textile, dye, metal plating, batteries and paint formulation [1]. In potable water, the amount of acceptable limit of $\mathrm{Pb}(\mathrm{II})$ is $0.01 \mathrm{mg} \mathrm{L}^{-1}$ and for Cd (II) is $0.003 \mathrm{mg} \mathrm{L}^{-1}$. These heavy metals may generate long-term harm in human beings, including lung fibrosis, dyspnea, anemia, muscle and joint pains, kidney damage, high blood pressure, etc. [2]. Because of their poisonous nature and high risk of accumulation it presents a serious threat to the environment, it is significant to reduce the amount of $\mathrm{Cd}$ (II) and $\mathrm{Pb}$ (II) from the wastewater before being directly discharged into the environment. Currently, biosorption has been strongly recommended by researchers as an efficient and economical technique to reduce the amount of heavy metals present in the different industrial wastewater sources [3-6].

Chitosan is used as an adsorbent to remove heavy metals in many studies due to its low-cost, abundance, and high selectivity against contaminants $[7,8]$. Chitosan can effectively adsorb various kinds of particles, including heavy metal ions based on the presence of hydroxyl $(-\mathrm{OH})$ and amino $\left(-\mathrm{NH}_{2}\right)$ functional groups [9]. In order

$\triangle$ Linh My Nguyen, linhnm@hcmute.edu.vn | 'Department of Environmental Technology, University of Technology and Education, HCMC, 264 Hoang Dieu 2 St, Linh Chieu Ward, Thu Duc District, Ho Chi Minh City, Vietnam. 
to augment the acid resistance condition of the chitosan, the chemical crosslink process was conducted with some specific agents such as glutaraldehyde, acid citric and epichlorohydrin [10-12]. For this research, to improve the raw chitosan acid stability and its mechanical strength, glutaraldehyde was applied to crosslink it. In contrast, the crosslinked polymer network affected the functional groups on the chitosan surface; which lead to decrease of its adsorption abilities. Currently, sugar bagasse, considered as waste after the extraction sugar juice from crushed cane, has been reported as a potential, low-cost biosorbent based on an agriculture by-product. The constituent of sugar bagasse are hemicellulose and lignin which process many oxygen functional groups, for instance hydroxyl; carboxyl and phenol groups $[13,14]$. In this regard, sugar bagasse was prepared into activated sugar bagasse ash via microwave radiation to enhance its adsorption capacity and immobilized on the crosslinked chitosan beads.

The purpose of this research is to evaluate the adsorption abilities of the composite material between glutaraldehyde-crosslinked chitosan and activated sugar bagasse ash (ASB-CBs) for reduction of $\mathrm{Cd}$ (II) and $\mathrm{Pb}$ (II) from liquid solutions. To evaluate the parameters affecting the biosorption process such as solution $\mathrm{pH}$, contact time, and temperature, the batch experiments were conducted. The adsorption kinetics were analyzed by applying the pseudo-first-order and pseudo-second-order models. The mechanism of metal ions adsorption through the modified crosslinked chitosan beads (ASB-CBs) was also examined for further elucidation this biosorption process.

\section{Materials and methods}

\subsection{Materials}

The standard solution of $\mathrm{Pb}$ (II) and Cd (II) (1000 mg L ${ }^{-1}$ ) was provided by Merck Company (Germany). All reagents as well as chitosan used in this research were analytical graded and supplied by Sigma Aldrich. The sugar bagasse used in this work was collected from the Plantation Thanh Long (Tay Ninh, Vietnam). The sugar bagasse was dried, ground and sieved to the size from 0.1 to $0.15 \mathrm{~mm}$ for subsequent experiments.

\subsection{Preparation of microwave activated sugar bagasse ash}

Sugar Bagasse Ash (SBA, $10 \mathrm{~g}$ ) was mixed with $10 \mathrm{~mL}$ of $91 \% \mathrm{H}_{3} \mathrm{PO}_{4}$ in a porcelain beaker. The mixture was put into microwave model SHARP R-20A1(S)VN for $5 \mathrm{~min}$ at $500 \mathrm{~W}$. The product was left to room temperature then centrifuged to wash until $\mathrm{pH}$ of solution was at 6.0-6.5.
The final result was dried in oven at $80^{\circ} \mathrm{C}$ in $3 \mathrm{~h}$ to obtain the activated sugar bagasse ash (ASB) which will be used to modified on the crosslinked chitosan beads later.

\subsection{Composite biosorbents preparation}

Composite biosorbents were formulated by mixing chitosan powder $(5 \mathrm{~g})$ with activated sugar bagasse ash $(1 \mathrm{~g})$ dissolved into acetic acid (7\%) $(240 \mathrm{~mL})$ and left for $16 \mathrm{~h}$. The slurry was poured into an alkali coagulating solution $\left(\mathrm{H}_{2} \mathrm{O}\right.$ : methanol: $\left.\mathrm{NaOH}=4: 5: 1, \mathrm{w} / \mathrm{w} / \mathrm{w}\right)(200 \mathrm{~mL})$, the result are beads that have an average diameter of $3.5 \mathrm{~mm}$. The products (ASB-CBs) were washed away by using distilled water to remove the residual $\mathrm{NaOH}$ [15-17]. In order to increase the acid resistance ability of the composite adsorbents, the wet ASB-CBs were mixed with a solution of glutaraldehyde (fixed at 1:2) within $16 \mathrm{~h}$. The final beads were rinsed multiple times to remove the residual glutaraldehyde using distilled water. The end result (ASB-CBs) was dehydrated at $80^{\circ} \mathrm{C}$ in an oven for $12 \mathrm{~h}$. SEM, FTIR were analyzed to investigate the characteristic of biosorbent.

\subsection{Adsorption experiments}

The batch adsorption tests were carried out to evaluate the different parameters affected such as biosorbent dose, $\mathrm{pH}$, agitated time, initial concentration of heavy metals on the removal efficiency of metal ions. The affecting of $\mathrm{pH}$ parameter was studied with the initiate $\mathrm{pH}$ from 3.0 to 8.0. The effect of contact time was carried out at $303 \mathrm{~K}$ and $200 \mathrm{rpm}$. The ASB-CBs $\left(2 \mathrm{~g} \mathrm{~L}^{-1}\right)$ was stirred with a metal ions solution $(100 \mathrm{~mL})$. After been completely mixed by using a shaker incubator (model LM-570RD) at $303 \mathrm{~K}$ and $200 \mathrm{rpm}$, the residual concentration of metal ions was measured using an atomic absorption spectrophotometer (Spectra AA 220, FS Varian). Different concentrations of metal ions ranging from 10 to $250 \mathrm{mg} \mathrm{L}^{-1}$ were examined under the optimal temperature, $\mathrm{pH}$, agitation time and biosorbent dose that have been found in the earlier tests.

The load of a single metal ion adsorbed on the surface of the adsorbent at equilibrium and time, $\mathrm{q}_{\mathrm{e}}$ and $\mathrm{q}_{\mathrm{t}}$ respectively, in $\mathrm{mg} \mathrm{g}^{-1}$ were estimated based on the equations as follow:

$q_{e}=\frac{\left(C_{0}-C_{e}\right) \times V}{m}$

$q_{t}=\frac{\left(C_{0}-C_{t}\right) \times V}{m}$

where $C_{0}, C_{e}$, and $C_{t}$ are the initial concentrations of metal ion, at equilibrium and at time $\mathrm{t}$ in $\mathrm{mg} \mathrm{L}^{-1}$, correspondingly, 

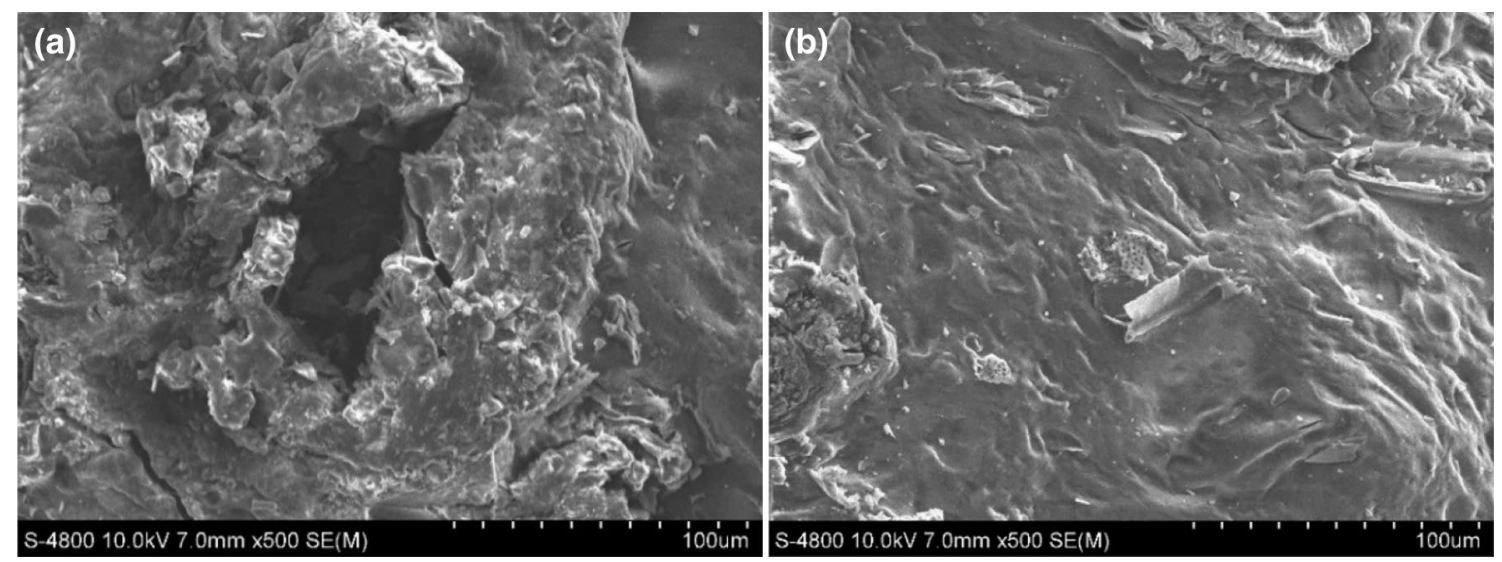

Fig. 1 SEM images of the $\mathbf{a}$ ASB-CBs, $\mathbf{b}$ metal ions-adsorbed ASB-CBs

(a)

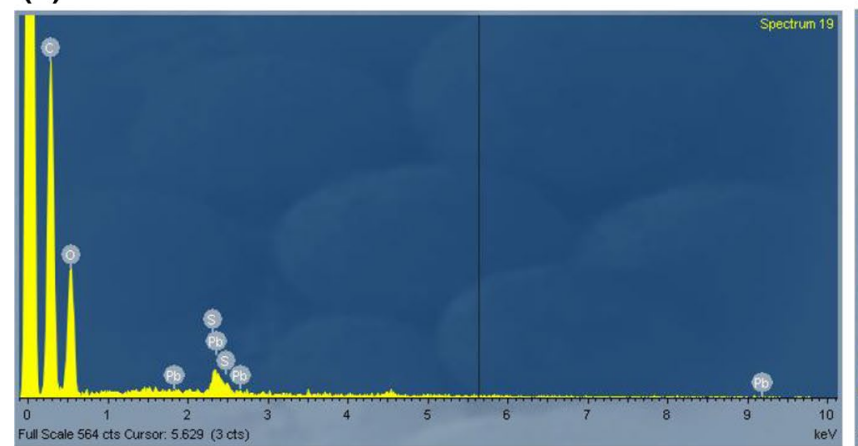

(b)

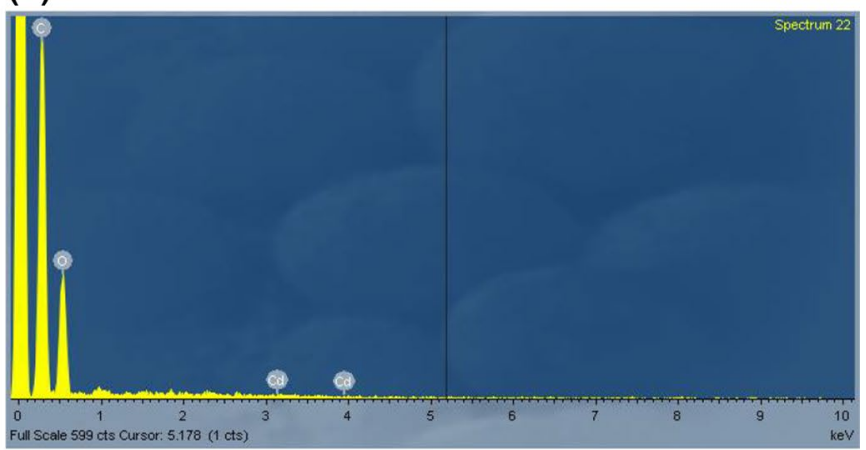

Fig. 2 EDX images of the $\mathbf{a} \mathrm{Pb}(\mathrm{II})$-adsorbed ASB-CBs, b Cd (II)-adsorbed ASB-CBs

$V$ represents the solution volume $(\mathrm{L})$, and $\mathrm{m}$ symbolizes the adsorbent dose used (g).

\section{Results}

\subsection{Characterization of the biosorbents}

The surface morphology of the biosorbents (ASB-CBs) before and after metal ions adsorption was studied using SEM analysis. The SEM images of ASB-CBs before and after metal uptake, as illustrated in Fig. 1a, b, display significant structure changes. The ASB-CBs surfaces are rough, dense and porous texture. However, after contact with $\mathrm{Pb}$ (II) and Cd (II), the porous texture disappeared and turn into smooth and tighter structure. The EDX images (Fig. 2a, b) show that $\mathrm{Pb}$ (II) and $\mathrm{Cd}$ (II) are well-adsorbed onto the composite materials.

The infrared spectrum analyzes of $C B s, A S B-C B s, P b$ adsorbed ASB-CBs and Cd-adsorbed ASB-CBs all had widespread igniting scales at $4000 \div 3000 \mathrm{~cm}^{-1}$ indicating

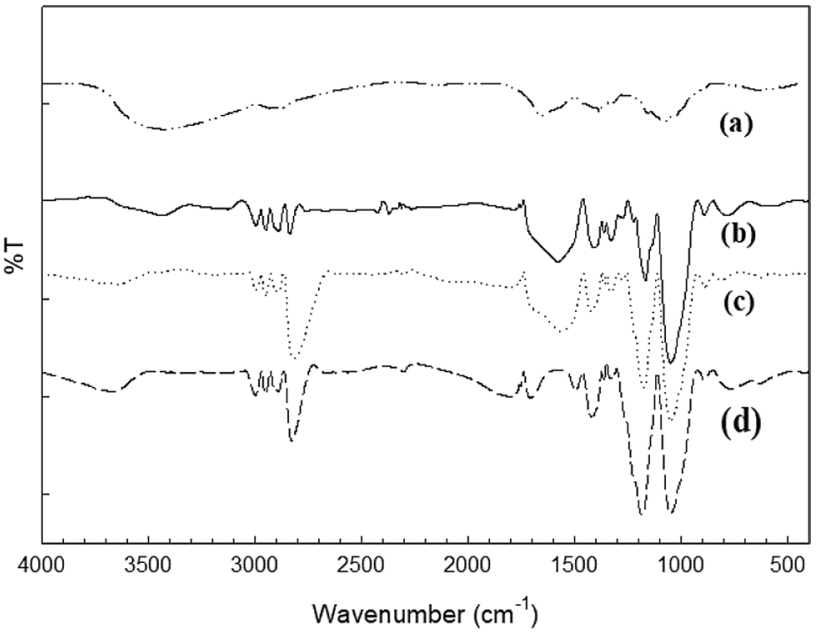

Fig. 3 FTIR spectra of the $\mathbf{a} C B s, \mathbf{b}$ ASB-CBs, $\mathbf{c}$ Pb-adsorbed ASB-CBs and $\mathbf{d}$ Cd-adsorbed ASB-CBs 
functional groups $-\mathrm{OH},-\mathrm{NH}_{2},-\mathrm{COO}$ and $\mathrm{C}-\mathrm{H}$ aromatics. In particular, the presence of strong intensities at $1647.10 \mathrm{~cm}^{-1}, 1658.67 \mathrm{~cm}^{-1}$ (Fig. 3b) and $1642.31 \mathrm{~cm}^{-1}$, $1639.59 \mathrm{~cm}^{-1}$ has a combined carboxylate functional group $\mathrm{NH}_{2}$ [18]. The $1544.88 \mathrm{~cm}^{-1}$ spectrum corresponds to the quaternary amine group. Peaks at $1317.29 \mathrm{~cm}^{-1}$ and $1380.94 \mathrm{~cm}^{-1}$ in ASB-CBs showed $\mathrm{C}-\mathrm{H}$ groups. The adsorption peaks have a weak intensity of $669.29 \mathrm{~cm}^{-1}$ and $570.89 \mathrm{~cm}^{-1}$ due to the metal oxide bonding of $\mathrm{M}-\mathrm{O}$ [19]. Some FTIR spectral absorption bands after adsorption of metal ions decreased the intensity indicating that the shift to low-spectrum bands indicated that there was a linkage between the functional groups and the metal oxide as illustrated in Fig. 3c, d). Changes in the absorption spectra after metal ions adsorption showed the successful preparation of absorbable material. Functional substituent groups on the materials include the $-\mathrm{OH},-\mathrm{CH}_{2},-\mathrm{CH}_{3}$, $-\mathrm{COO},-\mathrm{NH}_{2},-\mathrm{COOH},-\mathrm{C}-\mathrm{H},-\mathrm{CH}_{2}$.

\subsection{Effect of pH}

The $\mathrm{pH}$ of the solution significantly impacts the adsorption capacity, Fig. 4 illustrates the effect of the initial pH on the quantity of metal ions adsorbed onto ASB-CBs. The amount of removed metal ions increased with the increasing of $\mathrm{pH}$ from 3 to 5 . The maximum adsorption capacity was found at $\mathrm{pH} 5.0$ in which $\mathrm{Pb}$ (II) biosorbed is $11.79 \mathrm{mg} \mathrm{g}^{-1}$ and $\mathrm{Cd}$ (II) is $12.14 \mathrm{mg} \mathrm{g}^{-1}$ at initial metal ions concentration of $25 \mathrm{mg} \mathrm{L}^{-1}$. Nevertheless, as the pH increments over 7.0, the biosorption volume reduces due to the precipitation of the metal hydroxide. As a result, $\mathrm{pH} 5.0$ was chosen as the optimum $\mathrm{pH}$ for subsequent experiments. Also, many previous studies report $\mathrm{pH} 5.0-6.0$ as the optimum $\mathrm{pH}$ for heavy metals adsorption onto biosorbents [4, 20-22].

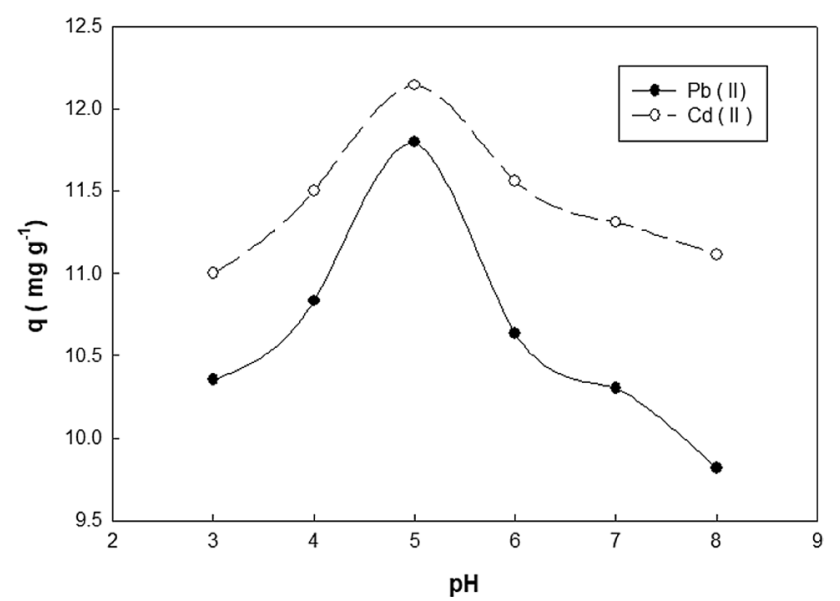

Fig. 4 The effect of $\mathrm{pH}$ on the adsorption capacity of metal ions on the ASB-CBs (at $303 \mathrm{~K}$ ) and an initial concentration of metal ions $\left(25 \mathrm{mg} \mathrm{L}^{-1}\right)$

\subsection{The biosorbent dose effect on metal ions biosorption}

A significant parameter that highly affects the biosorption capacity is the dose of adsorbent. The adsorption tests were carried out with the range of ASB-CBs between 0.5 and $5 \mathrm{~g} \mathrm{~L}^{-1}$ under the same conditions, for instance temperature, $\mathrm{pH}$, initial metal ions concentration and agitating time. The Fig. 5 illustrates the adsorption capacity effect of ASB-CBs. By increasing the absorbent dose, the amount of metal ions absorb on ASB-CBs decreases. Due that the adsorption sites have been saturated on the surface of the biosorbent when the dose is incremented, no more adsorption occurs after the equilibrium point [12].

\subsection{Kinetic of adsorption process}

In order to investigate the adsorption rate and the step which control the rate reaction, such as chemical reaction or mass transfer, kinetic models are used. The pseudo-firstorder and the pseudo-second-order kinetic models were employed to determine the data obtained from the tests. The pseudo-first-order kinetic model equation is:

$\ln \left(q_{e}-q_{t}\right)=\ln q_{e}-k_{1} t$

where $k_{1}$ is the first-order rate constant $\left(1 \mathrm{~min}^{-1}\right)$ and $t$ is the contact time (minutes). The pseudo-second-order kinetic model equation is:

$\frac{t}{q_{t}}=\frac{1}{k_{2} q_{e}^{2}}+\left(\frac{1}{q_{e}}\right) t$

where $k_{2}$ is the second-order rate constant $\left(\mathrm{g} \mathrm{mg}^{-1} \mathrm{~min}^{-1}\right)$.

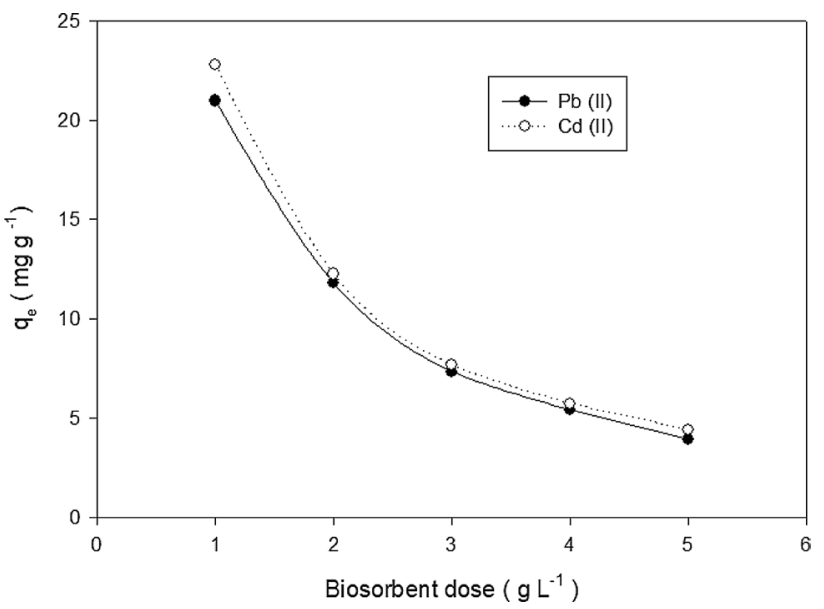

Fig. 5 Effect of adsorbent dose on the removal of metal ions on the ASB-CBs (at $303 \mathrm{~K}$ ), pH 5.0, and an initial concentration of metal ions ( $25 \mathrm{mg} \mathrm{L}^{-1}$ )

\section{SN Applied Sciences}




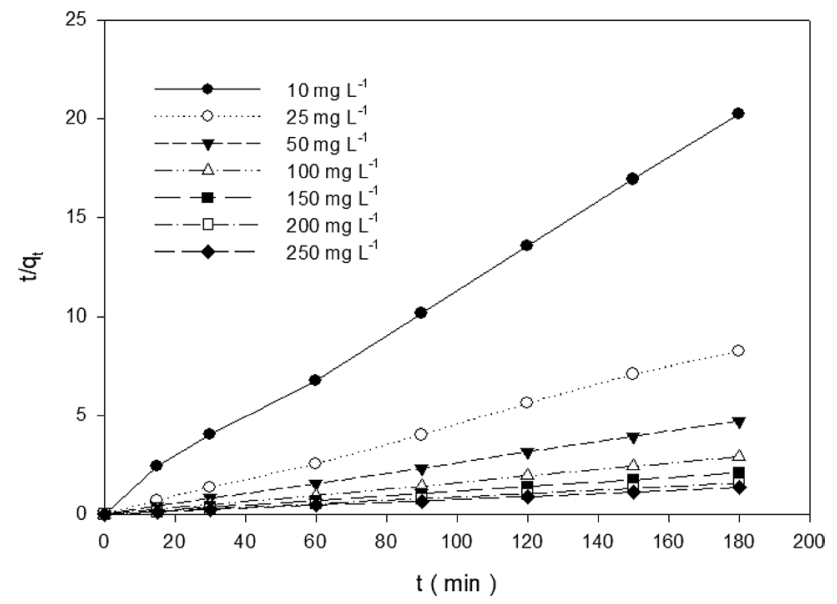

Fig. 6 Graph of the pseudo-second-order model for the adsorption of $\mathrm{Pb}$ (II) on the ASB-CBs ( $303 \mathrm{~K}), \mathrm{pH} 5.0$, and different initial concentrations of $\mathrm{Pb}(\mathrm{II})$

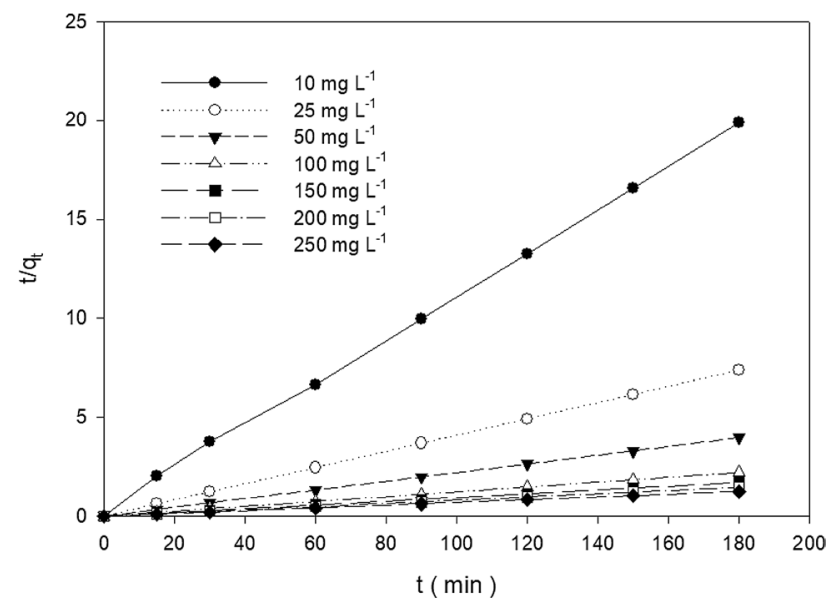

Fig. 7 Graph of the pseudo-second-order model for the adsorption of Cd (II) on the ASB-CBs (303 K), pH 5.0, and different initial concentrations of $\mathrm{Cd}$ (II)

The value of $k_{1}$ was estimated by the plot between In $\left(q_{\mathrm{e}}-q_{\mathrm{t}}\right)$ and $t$ (not shown), and the correlation coefficient $\left(r^{2}\right)$ was also found. The plot of $\left(t / q_{t}\right)$ versus $t$ (Figs. 6,7$)$ was used to determine $k_{2}$ and $r^{2}$.
The kinetic parameters of the biosorption process for $\mathrm{Pb}(\mathrm{II})$ and $\mathrm{Cd}$ (II) are listed in Tables 1 and 2, correspondingly. The $r^{2}$ values in both metal ions adsorption clarified that the experimental data used, fitted with the pseudosecond-order model $\left(r^{2}>0.9995\right)$. These results validate that the pseudo-second-order model can indicate that the rate-limiting step in metal ions biosorption on the ASB-CBs is the chemisorption.

\subsection{Equilibrium modeling}

The following equation described the linear form of the Freundlich model $[23,24]$.

$\ln q_{e}=\ln K_{F}+(1 / n) \ln C_{e}$

where $K_{\mathrm{F}}$ is a constant indicating the relative adsorption capacity of the biosorbent $\left(\mathrm{mg}^{1-(1 / n)} \mathrm{L}^{1 / n} \mathrm{~g}^{-1}\right)$, and $n$ is a constant indicating the adsorption intensity.

The values of $K_{\mathrm{F}}$ and $n$ found from the graph of $\ln q_{\mathrm{e}}$ and $\ln C_{\mathrm{e}}$ at different temperatures are reported in Tables 3 and 4. The $n$ value indicates the trend of the adsorption process; if $n=1$, a linear adsorption occur; if $n<1$, it indicates that is a chemical process; if $n>1$, it indicates that is a physical process [25]. The obtained correlation coefficient $r^{2}$ is larger than 0.998 , indicating the feasibility of the application of the Freundlich equation. In this research, the value of $n$ is found between 0.7 and 0.8 that is almost equal to 1.0 , demonstrating not only chemical but also physical process of metal ions biosorption on the ASB-CBs.

In order to reveal the adsorption behavior on the surface $[16,26,27]$, the Langmuir isotherm model was applied. The linearized Langmuir equation is:

$\frac{C_{e}}{q_{e}}=\left(\frac{1}{K_{L} \times q_{\max }}\right)+\left(\frac{1}{q_{\max }}\right) \times C_{e}$

where $q_{\max }$ is the maximum quantity of adsorption $\left(\mathrm{mg} \mathrm{g}^{-1}\right)$, and $K_{\mathrm{L}}$ is the Langmuir constant $\left(\mathrm{L} \mathrm{mg}^{-1}\right)$.

The values of $K_{\mathrm{L}}$ and $q_{\mathrm{m}}$ found from the graph $C_{\mathrm{e}} / q_{\mathrm{e}}$ and $C_{\mathrm{e}}$, listed in Tables 3 and 4, compares the experimental data with the ones fitted by the Langmuir equation (Eq. 6) at different temperatures.
Table 1 The kinetic parameters of the adsorption of $\mathrm{Pb}$ (II) on the ASB-CBs (at $303 \mathrm{~K}$ ) and $\mathrm{pH} 5.0$

\begin{tabular}{|c|c|c|c|c|c|}
\hline \multirow[t]{2}{*}{$C_{0}\left(\mathrm{mg} \mathrm{L}^{-1}\right)$} & \multicolumn{2}{|c|}{ Pseudo-first-order model } & \multicolumn{3}{|c|}{ Pseudo-second-order model } \\
\hline & $k_{1}\left(1 \min ^{-1}\right)$ & $r^{2}(-)$ & $k_{2}\left(\mathrm{~g} \mathrm{mg}^{-1} \mathrm{~min}\right)$ & $q_{\mathrm{e}}\left(\mathrm{mg} \mathrm{g}^{-1}\right)$ & $r^{2}(-)$ \\
\hline 25 & 1.85 & 0.9856 & $0.0336 \pm 0.0005$ & $8.4 \pm 0.6$ & 0.9990 \\
\hline 50 & 1.76 & 0.9452 & $0.0134 \pm 0.0003$ & $15.2 \pm 1.5$ & 0.9979 \\
\hline 100 & 0.99 & 0.9234 & $0.0118 \pm 0.0004$ & $28.1 \pm 1.7$ & 0.9966 \\
\hline 150 & 0.76 & 0.9080 & $0.0103 \pm 0.0002$ & $41.2 \pm 2.1$ & 0.9984 \\
\hline 200 & 0.63 & 0.9452 & $0.010 \pm 0.0002$ & $52.1 \pm 2.4$ & 0.9995 \\
\hline 250 & 0.52 & 0.9051 & $0.0051 \pm 0.0001$ & $56.4 \pm 2.3$ & 0.9990 \\
\hline
\end{tabular}


Table 2 The kinetic parameters of the adsorption of $\mathrm{Cd}$ (II) on the ASB-CBs (at $303 \mathrm{~K}$ ) and $\mathrm{pH} 5.0$

\begin{tabular}{|c|c|c|c|c|c|}
\hline \multirow[t]{2}{*}{$C_{0}\left(\mathrm{mg} \mathrm{L}^{-1}\right)$} & \multicolumn{2}{|c|}{ Pseudo-first-order model } & \multicolumn{3}{|c|}{ Pseudo-second-order model } \\
\hline & $k_{1}\left(1 \min ^{-1}\right)$ & $r^{2}(-)$ & $k_{2}\left(\mathrm{~g} \mathrm{mg}^{-1} \mathrm{~min}\right)$ & $q_{\mathrm{e}}\left(\mathrm{mg} \mathrm{g}^{-1}\right)$ & $r^{2}(-)$ \\
\hline 25 & 1.65 & 0.9243 & $0.04336 \pm 0.0005$ & $12.4 \pm 0.6$ & 0.9990 \\
\hline 50 & 1.46 & 0.9532 & $0.0345 \pm 0.0003$ & $22.0 \pm 1.5$ & 0.9981 \\
\hline 100 & 1.29 & 0.9183 & $0.0219 \pm 0.0004$ & $39.3 \pm 1.7$ & 0.9943 \\
\hline 150 & 1.11 & 0.8993 & $0.0131 \pm 0.0002$ & $45.2 \pm 2.1$ & 0.9979 \\
\hline 200 & 1.05 & 0.9012 & $0.0105 \pm 0.0002$ & $59.1 \pm 2.4$ & 0.9995 \\
\hline 250 & 0.87 & 0.9192 & $0.0101 \pm 0.0001$ & $63.4 \pm 2.3$ & 0.9990 \\
\hline
\end{tabular}

Table 3 The isotherm parameters of the biosorption process of $\mathrm{Pb}$ (II) on the ASB$\mathrm{CBs}$ at $\mathrm{pH} 5.0$

\begin{tabular}{llllllll}
\hline$T(\mathrm{~K})$ & \multicolumn{2}{l}{ Langmuir isotherm } & & \multicolumn{3}{l}{ Freundlich isotherm } \\
\cline { 2 - 3 } & $K_{\mathrm{L}}\left(\mathrm{L} \mathrm{mg}^{-1}\right)$ & $q_{\max }\left(\mathrm{mg} \mathrm{g}^{-1}\right)$ & $r^{2}(-)$ & & $\begin{array}{l}K_{\mathrm{F}}\left(\mathrm{mg}^{1-(1 / n)}\right. \\
\left.\mathrm{L}^{1 / n} \mathrm{~g}^{-1}\right)\end{array}$ & $n(-)$ & $r^{2}(-)$ \\
\hline 298 & 0.023 & 117.2 & 0.9313 & 3.475 & 0.349 & 0.9959 \\
303 & 0.045 & 142.8 & 0.9019 & & 4.188 & 0.461 & 0.9968 \\
308 & 0.087 & 169.0 & 0.9512 & & 5.961 & 0.733 & 0.9931 \\
313 & 0.0117 & 185.1 & 0.9415 & & 10.191 & 0.769 & 0.9980 \\
\hline
\end{tabular}

Table 4 The isotherm parameters of the biosorption process of Cd (II) on the ASB$\mathrm{CBs}$ at $\mathrm{pH} 5.0$

\begin{tabular}{llllllll}
\hline$T(\mathrm{~K})$ & \multicolumn{2}{l}{ Langmuir isotherm } & & \multicolumn{4}{l}{ Freundlich isotherm } \\
\cline { 2 - 3 } & $K_{\mathrm{L}}\left(\mathrm{L} \mathrm{mg}^{-1}\right)$ & $q_{\max }\left(\mathrm{mg} \mathrm{g}^{-1}\right)$ & $r^{2}(-)$ & & $\begin{array}{l}K_{\mathrm{F}}\left(\mathrm{mg}^{1-(1 / n)}\right. \\
\left.\mathrm{L}^{1 / n} \mathrm{~g}^{-1}\right)\end{array}$ & $n(-)$ & $r^{2}(-)$ \\
\hline 298 & 0.037 & 76.9 & 0.9004 & & 1.824 & 0.261 & 0.999 \\
303 & 0.049 & 77.5 & 0.8901 & & 1.447 & 0.1605 & 0.9971 \\
308 & 0.064 & 78.1 & 0.9428 & & 1.58 & 0.1987 & 0.9911 \\
313 & 0.081 & 84.0 & 0.9518 & & 2.078 & 0.3176 & 0.9982 \\
\hline
\end{tabular}

$q_{e}=\frac{q L_{e \max }}{1+K_{L} q_{\max }}$

The maximum amount of $\mathrm{Pb}$ (II) and $\mathrm{Cd}$ (II) adsorption are $185.18 \mathrm{mg} \mathrm{g}^{-1}$ and $84.03 \mathrm{mg} \mathrm{g}^{-1}$ at $313 \mathrm{~K}$, respectively. The ASB-CBs in this study show improvement and promising performance for metal ions removal compare with other biosorbents in previous studies.

\subsection{Thermodynamic}

The Gibbs energy $(\Delta G)\left(\mathrm{kJ} \mathrm{mol}^{-1}\right)$, the enthalpy change $(\Delta H)\left(\mathrm{kJ} \mathrm{mol}^{-1}\right)$, and the entropy change $(\Delta S)\left(\mathrm{J} \mathrm{mol}^{-1} \mathrm{~K}\right)$ of an adsorption process can be estimated by [28]

$\Delta G=-R T \ln K_{L}$

where $T$ is the absolute temperature $(\mathrm{K})$ and $R$ is the universal gas constant $\left(8.314 \mathrm{~J} \mathrm{~mol}^{-1} \mathrm{~K}^{-1}\right.$ ). The values of $\Delta H$ and $\Delta S$ can be obtained from the slope and intercept of the graph of In $K_{\mathrm{L}}$ against $1 / T$ based on the van't Hoff equation
Table 5 The thermodynamic parameters of the biosorption of $\mathrm{Pb}$ (II) on the ASB-CBs at $\mathrm{pH} 5.0$

\begin{tabular}{llll}
\hline$T(\mathrm{~K})$ & $\Delta G\left(\mathrm{~kJ} \mathrm{~mol}^{-1}\right)$ & $\Delta H\left(\mathrm{~kJ} \mathrm{~mol}^{-1}\right)$ & $\Delta S\left(\mathrm{~J} \mathrm{~mol}^{-1} \mathrm{~K}\right)$ \\
\hline 298 & -5.67 & $19.49 \pm 0.9$ & $111.1 \pm 8.9$ \\
303 & -6.04 & & \\
308 & -8.09 & & \\
313 & -9.62 & & \\
\hline
\end{tabular}

$\ln K_{L}=\frac{\Delta S}{R}-\frac{\Delta H}{R T}$

Tables 5 and 6 show the thermodynamic parameters of the adsorption process of $\mathrm{Pb}$ (II) and $\mathrm{Cd}$ (II) on the ASB-CBs. The negative $\Delta G$ values which indicated the metal ions adsorption on the ASB-CBs was spontaneous. The values of $\Delta H$ and $\Delta S$ were $19.49 \mathrm{~kJ} \mathrm{~mol}^{-1}$ and $111.1 \mathrm{~J} \mathrm{~mol}^{-1} \mathrm{~K}^{-1}$, correspondingly in case of $\mathrm{Pb}(\mathrm{II})$; $15.9 \mathrm{~kJ} \mathrm{~mol}^{-1}$ and $110.1 \mathrm{~J} \mathrm{~mol}^{-1} \mathrm{~K}^{-1}$ in case of $\mathrm{Cd}$ (II). The positive enthalpy change $(\Delta H)$ reveals the endothermic nature. The entropy change value is positive, indicating 
Table 6 The thermodynamic parameters of the biosorption of $\mathrm{Cd}$ (II) on the ASB-CBs at pH 5.0

\begin{tabular}{llll}
\hline$T(\mathrm{~K})$ & $\Delta G\left(\mathrm{~kJ} \mathrm{~mol}^{-1}\right)$ & $\Delta H\left(\mathrm{~kJ} \mathrm{~mol}^{-1}\right)$ & $\Delta S\left(\mathrm{~J} \mathrm{~mol}^{-1} \mathrm{~K}\right)$ \\
\hline 298 & -7.47 & $15.9 \pm 0.7$ & $110.1 \pm 7.8$ \\
303 & -6.33 & & \\
308 & -7.01 & & \\
313 & -8.57 & & \\
\hline
\end{tabular}

increased randomness at the surface of the ASB-CBs during the process [29].

Acknowledgements I would like to thank the Faculty of Chemical and Food Technology from HCMC University of Technology and Education, I also would like to express my deep gratitude my colleagues and my family for their support in this research.

\section{Compliance with ethical standards}

Conflict of interest We hereby pledge that this study is a true scientific research of my own, conducted under my research group. The references in the manuscript are from scientific papers, books have been verified and published widely. We promise to quote the source clearly in the reference list. The research results in this project are done by the group itself strictly, honestly and not overlapping with other topics.

\section{References}

1. Gavrilescu M (2004) Removal of heavy metals from the environment by biosorption. Eng Life Sci 4(3):219-232

2. Ahmad A, Khatoon A, Mohd-Setapar S-H, Kumar R, Rafatullah M (2016) Chemically oxidized pineapple fruit peel for the biosorption of heavy metals from aqueous solutions. Desalination Water Treat 57:6432-6442

3. Arief VO, Trilestari K et al (2008) Recent progress on biosorption of heavy metals from liquids using low cost biosorbents: characterization, biosorption parameters and mechanism studies. CLEAN Soil Air Water 36(12):937-962

4. Bayo J (2012) Kinetic studies for Cd(II) biosorption from treated urban effluents by native grapefruit biomass (Citrus paradisi L.): the competitive effect of $\mathrm{Pb}(\mathrm{II}), \mathrm{Cu}(\mathrm{II})$ and $\mathrm{Ni}(\mathrm{II})$. Chem Eng J 191:278-287

5. Chojnacka K (2010) Biosorption and bioaccumulation: the prospects for practical applications. Environ Int 36(3):299-307

6. Kapoor A, Viraraghavan T (1995) Fungal biosorption: an alternative treatment option for heavy metal bearing wastewaters-a review. Biores Technol 53(3):195-206

7. Wan Ngah WS, Teong LC et al (2011) Adsorption of dyes and heavy metal ions by chitosan composites: a review. Carbohydr Polym 83(4):1446-1456

8. Wu F-C, Tseng R-L et al (2010) A review and experimental verification of using chitosan and its derivatives as adsorbents for selected heavy metals. J Environ Manag 91(4):798-806

9. Vold IMN, Vårum KM et al (2003) Binding of ions to chitosan: selectivity studies. Carbohydr Polym 54(4):471-477

10. Beppu MM, Vieira RS et al (2007) Crosslinking of chitosan membranes using glutaraldehyde: effect on ion permeability and water absorption. J Membr Sci 301(1-2):126-130
11. Monteiro OAC Jr, Airoldi C (1999) Some studies of crosslinking chitosan-glutaraldehyde interaction in a homogeneous system. Int J Biol Macromol 26(2-3):119-128

12. Suc NV, Ly HTY (2013) Lead (II) removal from aqueous solution by chitosan flake modified with citric acid via crosslinking with glutaraldehyde. J Chem Technol Biotechnol 88:1641-1649

13. Foo KY, Lee LK et al (2013) Preparation of activated carbon from sugarcane bagasse by microwave assisted activation for the remediation of semi-aerobic landfill leachate. Biores Technol 134:166-172

14. Hamza IA, Martincigh BS, Ngila JC, Nyamori VO (2013) Adsorption studies of aqueous $\mathrm{Pb}$ (II) onto a sugarcane bagasse/ multi-walled carbon nanotube composite. Phys Chem Earth 66:157-166

15. Dalida MLP, Mariano AFV et al (2011) Adsorptive removal of $\mathrm{Cu}$ (II) from aqueous solutions using non-crosslinked and crosslinked chitosan-coated bentonite beads. Desalination 275(1-3):154-159

16. Eser $A$, Nüket Tirtom $V$ et al (2012) Removal of nickel(II) ions by histidine modified chitosan beads. Chem Eng J 210:590-596

17. Liu Y-G, Liao T et al (2013) Biosorption of copper(II) from aqueous solution by Bacillus subtilis cells immobilized into chitosan beads. Trans Nonferrous Met Soc China 23(6):1804-1814

18. Haque MN, Morrison GM et al (2007) Characteristics of arsenic adsorption to sorghum biomass. J Hazard Mat 145(1):30-35

19. Anandan K, Rajendran V (2011) Morphological and size effects of $\mathrm{NiO}$ nanoparticles via solvothermal process and their optical properties. Mat Sci Semicond Process 14(1):43-47

20. Al-Jariri JS, Khalili F (2010) Adsorption of $\mathrm{Zn}(\mathrm{II}), \mathrm{Pb}$ (II), $\mathrm{Cr}$ (III) and $\mathrm{Mn}$ (II) from water by Jordanian bentonite. Desalination Water Treat 21(1-3):308-322

21. Chen A-H, Liu S-C et al (2008) Comparative adsorption of $\mathrm{Cu}(\mathrm{II})$, $\mathrm{Zn}(\mathrm{II})$, and $\mathrm{Pb}(\mathrm{II})$ ions in aqueous solution on the crosslinked chitosan with epichlorohydrin. J Hazard Mater 154(1-3):184-191

22. Laus R, Costa TG et al (2010) Adsorption and desorption of $\mathrm{Cu}(\mathrm{II}), \mathrm{Cd}(\mathrm{II})$ and $\mathrm{Pb}$ (II) ions using chitosan crosslinked with epichlorohydrin-triphosphate as the adsorbent. J Hazard Mater 183(1-3):233-241

23. Cui $L$, Wu G et al (2010) Adsorption performance of nickel and cadmium ions onto brewer's yeast. Can J Chem Eng 88(1):109-115

24. Göksungur Y, Üren S et al (2005) Biosorption of cadmium and lead ions by ethanol treated waste baker's yeast biomass. Biores Technol 96(1):103-109

25. Ngah WSW, Fatinathan S (2006) Chitosan flakes and chitosanGLA beads for adsorption of $\mathrm{p}$-nitrophenol in aqueous solution. Colloids Surf A 277(1-3):214-222

26. Popuri SR, Vijaya Y et al (2009) Adsorptive removal of copper and nickel ions from water using chitosan coated PVC beads. Biores Technol 100(1):194-199

27. Ghaee A, Shariaty-Niassar M et al (2012) Adsorption of copper and nickel ions on macroporous chitosan membrane: equilibrium study. Appl Surf Sci 258(19):7732-7743

28. Sarı A, Tuzen $\mathrm{M}$ et al (2007) Biosorption of $\mathrm{Pb}$ (II) and $\mathrm{Ni}(\mathrm{II})$ from aqueous solution by lichen (Cladonia furcata) biomass. Biochem Eng J 37(2):151-158

29. Padmavathy V (2008) Biosorption of nickel(II) ions by baker's yeast: kinetic, thermodynamic and desorption studies. Biores Technol 99(8):3100-3109

Publisher's Note Springer Nature remains neutral with regard to jurisdictional claims in published maps and institutional affiliations. 